\title{
A profissão professor - crise de profissão ou profissão em crise?
}

José Pedro Boufleuer Universidade Regional do Noroeste do Estado do Rio Grande do Sul

\section{Resumo}

Pressupondo uma crise na profissão professor, o artigo analisa a "crise de profissão" com base num paradoxo em relação ao professor, que é a aposta no seu trabalho para o equacionamento de boa parte das mazelas da sociedade, ao mesmo tempo em que há uma baixa valorização de sua profissão. Já como "profissão em crise" aponta para três situações que a corroboram: os abalos e inversões acerca dos vínculos entre ordem política e educação, a perda do foco da ação do professor e a ausência de uma relação de intimidade com o conhecimento. Por fim, o artigo apresenta as imagens do professor "organista" e "recepcionista”, na expectativa de deixar mais patente a linha de argumentação apresentada.

Palavras-chave: Profissão professor. Crise da docência. Ordem política. Escola. Imagens da docência. 


\section{The teaching profession - a crisis of profession or a profession in crisis?}

Assuming a crisis in the teaching profession, the article analyzes this "crisis of profession" based on a paradox involving teachers, which is that their work is believed to be crucial in solving many of society's ills, while their profession is underappreciated. As to the "profession in crisis", it points to three situations that corroborate it: the upsets and inversions affecting the links between political order and education, the loss of focus of the teacher's work, and the lack of an intimate relationship with knowledge. Lastly, the article presents the images of the "organist" and "receptionist" teachers, with the intention of clarifying the line of argument presented.

Keywords: Teaching profession. Crisis in teaching. Political order. School. Images of teaching.

\section{La profesión docente - ¿crisis de profesión u ocupación en crisis?}

Suponiendo una crisis en la profesión de maestro, el artículo hace el análisis de la "crisis de la profesión" basado en una paradoja en relación con el maestro, que es la apuesta en su trabajo hacia la resolución de muchos de los males de la sociedad, mientras hay una baja plusvalía de su profesión. Ya como "profesión en crisis" apunta a tres situaciones donde corroboran: los tambaleos e inversiones acerca de los lazos entre el orden político y educación, la pérdida del enfoque de acción del maestro y la falta de una relación de intimidad con el conocimiento. Por último, el artículo presenta imágenes del maestro "organista" y "recepcionista" con el fin de hacer más accesible la línea de argumentaciones presentada.

Palabras-clave: Profesión Maestro. Crisis de la Docencia. Orden Político. Escuela. Imágenes de la Docencia. 


\section{Introdução}

Acerca da profissão de professor, há um debate que pressupõe uma crise a ela relacionada. Uma crise que se expressa, por um lado, como manifestação de insatisfações de toda ordem de quem se encontra no exercício do magistério, ao modo de um generalizado "mal-estar docente" (Esteve, 1999; Oliveira, 2006), e, de outro, como redução drástica de candidatos aos cursos de formação de professores, levando a fechamento de vagas em cursos de licenciatura, vinculados a tradicionais áreas de formação e de conhecimento, em diversas instituições de ensino superior. Os reflexos dessa crise se estendem, por sua vez, à futura geração universitária, hoje no ensino médio, para quem a carreira docente parece estar fora das possibilidades em questão.

Instigados pela problemática assim exposta, optamos por pensá-la com base nas duas hipóteses constantes do título deste ensaio. Consideraremos a primeira hipótese - crise de profissão - como se tratando de uma possível crise vinculada ao tipo de ocupação que alguém pode vir a ter como forma de inserirse no mercado de trabalho, mais propriamente no que concerne à existência de demanda de trabalho e expectativa de remuneração. Já a segunda hipótese - profissão em crise - vamos entendê-la como uma possível crise vinculada à identidade do profissional em questão, o professor, no que se refere à percepção do caráter de sua atividade, de seu papel na sociedade, entre outras dimensões. E é nesse sentido que vamos tentar caracterizar ambas as hipóteses, pensando em cada uma delas. Obviamente que as duas noções de crise não podem ser de todo separadas, já que se condicionam mutuamente. Na parte final deste texto, apresentaremos duas possíveis imagens de professor que, a nosso ver, ajudarão no esclarecimento de alguns pontos de vista, bem como no delineamento de perspectivas de enfrentamento da questão em pauta. Para evitar certa cacofonia pelo uso reiterado das expressões "professor" e "profissão", a expressão "docente" será tomada neste texto como equivalente a "professor".

\section{A hipótese da "crise de profissão" da docência}

Uma das ideias, senão a primeira, que costuma vir à cabeça quando se fala de uma crise de profissão da docência é que o emprego aí proporcionado é mal remunerado, ou seja, que a remuneração percebida como professor não permite um nível desejável de usufruto dos bens materiais e culturais que o mundo de hoje oferece. A expectativa de uma vida confortável e rica em vivências culturais, tal como oportunizada pela sociedade atual, não teria, portanto, na profissão docente uma via de realização, fazendo com que a opção pela docência seja pouco considerada pelos jovens na hora de se decidirem por uma carreira profissional, 
além de produzir certo desalento naqueles que já estão atuando como docentes.

Certamente temos que concordar que as expectativas salariais que podem ser alimentadas em relação a uma carreira determinam fortemente o interesse por ela. Além disso, parece evidente que os jovens mais bem preparados durante a educação básica, e que em regra se permitem ambições profissionais que demandam maior nível de exigência, tomam a expectativa de uma boa remuneração como um dos critérios de escolha de sua carreira profissional. Pelo que se sabe, o que ocorre em nosso país contrasta com o que vem acontecendo em países que se destacam exatamente pelos bons índices de desempenho educacional, como Finlândia e Coréia do Sul. Trata-se de países onde, em qualquer área de conhecimento, a carreira de maior prestígio é a daqueles que trabalham na docência. Com base nessas situações, a pesquisadora Mona Mourshed (2008) propõe tornar a docência uma profissão apenas para os melhores para, assim, melhorar a qualidade da educação'. A sinalização disso é feita com base no que ocorre naqueles países em que a seleção dos professores inclui análise do currículo e do desempenho acadêmico, entrevistas e acompanhamento do exercício profissional, o que resulta, conforme a pesquisadora, em que, de dez candidatos, apenas um consegue se tornar professor ${ }^{2}$. Parece óbvio que, em situações como essa, só em não conseguindo um emprego de professor na sua área, os egressos de cursos superiores vão exercer uma atividade de aplicação desse conhecimento, como que se contentando com um emprego de segunda categoria. Nessa linha de observações, pagar aos professores os melhores salários do mercado seria, evidentemente, a solução, com o que se resolveria não só a crise da profissão docente, mas, e de quebra, boa parte dos problemas de educação, já que ela contaria com os profissionais mais bem preparados em cada área de conhecimento.

Quanto ao entendimento de que a crise da profissão docente é basicamente uma crise de expectativa de salário, no entanto, podemos objetar dizendo que muitas outras carreiras profissionais também não contemplam essa expectativa de uma boa remuneração e que, nem por isso, sofrem do tipo de crise que parece afetar a docência. E, se considerarmos o salário inicial da maior parte das carreiras profissionais, possivelmente o do magistério não está entre os mais baixos. Além disso, é preciso considerar que a carreira docente oferece inúmeras oportunidades de ascensão, especialmente via formação continuada em níveis cada vez mais elevados, incluindo reconhecimento profissional e incremento da remuneração.

Com essas observações queremos reconhecer que a expectativa de remuneração afeta, sem dúvida, a profissão docente, ajudando a configurar a sua crise, mas que

1. A pesquisadora Mona Mourshed, da empresa de consultoria McKinsey, foi coordenadora do estudo intitulado "Como os sistemas escolares de melhor desempenho do mundo chegaram ao topo". Ela esteve no Brasil em 2008 lançando livro com os resultados da pesquisa.

2. Uma síntese das principais conclusões da pesquisa coordenada pela pesquisadora foi divulgada em reportagem da Revista Veja, edição 2.065, de 18 de junho de 2008, p. 128-130 (Acervo digital disponível em: http://veja.abril. com.br/acervodigital/home.aspx). 
não pode ser vista como a explicação cabal dessa questão.

De outra parte, uma crise de profissão poderia também estar vinculada ao campo de trabalho, na medida em que este estivesse se esgotando ou não mais demandando determinado profissional, no caso, o professor. Como exemplos de crises profissionais desse tipo tem-se, nos dias atuais, a do técnico que conserta vitrola e do mecânico que só entende de arrumar carburador, entre outros casos. Será que poderíamos identificar uma crise desse tipo em relação à docência? Máquinas, por exemplo, estariam tirando o emprego dos professores, como ocorreu com boa parte dos antigamente bem remunerados trabalhadores de bancos? Haveremos de convir que esse não é o caso dos professores. Afinal, crianças continuam nascendo, sendo que na cabeça de seus pais nem passa a ideia de não confiá-las a professores em escolas. Aliás, no contexto da República, a educação que sempre se afirma como um direito do cidadão constitui, mais propriamente, uma obrigação. Com isso, pode-se dizer, o próprio Estado garante a permanência desse campo de atuação. Acrescenta-se a isso os dados relativos à falta de professores para as vagas disponíveis, inclusive os de concursos públicos para o magistério que, em alguns estados, e em determinadas áreas, acabam recebendo inscrições em número inferior ao das vagas existentes. Enfim, como se diria em linguagem corrente, o mercado profissional da docência continua aquecido.

Disso tudo que acabamos dizendo sob o ponto de vista da hipótese de que estamos diante de uma crise profissional, podemos apontar para certo paradoxo que se expressa em relação ao professor. Por um lado, reafirma-se continuamente - papel da escola e do professor como imprescindíveis para a superação das mazelas da nossa sociedade. Problemas como a violência, a criminalidade, a corrupção, enfim, tudo o que põe em risco a convivência civilizada na sociedade humana é interpretado como resultante de uma educação deficitária, ou seja, como consequência da ausência de bons professores na formação dos indivíduos. De outra parte, essa mesma sociedade, que faz tão alta aposta no trabalho dos professores, parece não se incomodar com a baixa valorização dessa categoria profissional, expressa no padrão salarial a ela estabelecido, especialmente pelos poderes públicos, e, por consequência, com o fato de estarmos tendo, em regra, como professores das novas gerações os de menor êxito na sua própria formação.

Enfim, fizemos essas observações iniciais para contemplar a primeira hipótese levantada acerca da problemática em pauta. Sem dúvida, como buscamos sinalizar, há uma questão de valorização profissional que necessita ser enfrentada sob a forma de uma tomada de consciência por parte da sociedade e ao mesmo tempo vir a se expressar concretamente através de políticas públicas de Estado. 


\section{A hipótese da docência como uma "profissão em crise"}

Já enunciamos acima que, sob a hipótese de que a docência configura uma profissão em crise, refletiremos sobre a percepção do professor acerca do caráter do seu trabalho, do seu lugar na sociedade, entre outras dimensões. Assim, se no item anterior perguntávamos acerca do que os outros, e a sociedade em geral, pensam e esperam do professor e, também, acabam fazendo com ele, resultando no que chamamos de crise de profissão, no presente item vamos enfocar a crise na perspectiva do professor, a partir do modo como ele mesmo se põe como profissional, de como concebe a sua atividade.

De nossa parte, vamos pensar essa "profissão em crise" a partir de três linhas de reflexão. A primeira identifica uma crise quanto ao modo como o professor percebe o vínculo do seu trabalho com a ordem política constituída. A segunda visualiza uma crise no que se refere ao foco da ação docente. E uma terceira, que identifica uma crise no próprio ser do professor como aquele que professa, ou deveria professar, um determinado conhecimento.

\section{A crise no que se refere aos vínculos da ação docente com a ordem política}

As origens do professor como profissional que atua em espaços institucionalizados de ensino se vinculam à instauração da ordem republicana, resultante dos movimentos revolucionários e democratizantes dos séculos XVII e XVIII. Junto com a nova ordem política, surge a educação escolar como intimamente articulada ao projeto inclusivo e, quiçá, de aprimoramento progressivo desse novo modo de organizar e gestar a coisa pública. E é assim que o Estado assume a tutela da instrução via escola, considerando-a como exercício de uma função pública. Conservar as conquistas políticas e oferecer as condições para o desenvolvimento social e cultural tornam-se, por assim dizer, a própria razão de ser da atividade do professor e da educação escolar como um todo.

A educação moderna assume, então, esse caráter de instrução pública, em perspectiva de universalidade, tanto no que se refere a sua abrangência, quanto aos saberes a serem ensinados, distinguindo-se, por sua vez, de formas de educação como a familiar, a religiosa, entre outras com conotações particularistas. A legitimidade da ordem política ${ }^{3}$ confere legitimidade à educação como instância a seu serviço, com o que a escola surge não só como instituição tutelada pelo Estado, mas subordinada aos objetivos de sua conservação e renovação no âmbito

3. Por ordem política legítima compreendemos o gestar da coisa pública sob o princípio da liberdade de opiniões, à luz das quais se configuram os próprios objetivos a serem buscados, ou seja, política como um fazer sem teto, ressalvados os pressupostos da república. 
das possibilidades da própria democracia republicana. A identidade profissional do professor, por sua vez, configura-se a partir dos vínculos da educação escolar com a ordem política vigente.

Esses vínculos entre educação e ordem política entram em crise no momento em que esta última se torna ilegítima pela perda do seu esteio básico, que é a democracia. Foi isso que ocorreu no Brasil durante o período da ditadura militar, instaurado com o golpe militar de $1964^{4}$. Nesse contexto, a relação de subordinação da educação para com a ordem política converte-se em relação de subversão. E isso, justificadamente, pois como alguém poderia ser a favor, ou subserviente, a um regime autoritário que censurava, prendia, torturava e matava? Ou, conforme expressão da época, como poderia alguém ser lacaio da ditadura?

Quebram-se, assim, os vínculos entre a ordem política e a educação nos moldes como haviam sido instaurados na modernidade. Na prática, observa-se uma inversão na relação entre as duas instâncias. Historicamente a ordem política tinha na educação uma forma de sua reprodução e consolidação, já que, instituída por aquela, esta se entendia como necessariamente sintonizada com o seu instituinte, no caso, com as expectativas inerentes ao Estado. No novo contexto aqui referido, de contestação da ordem política vigente, a educação se assume como força instituinte de uma nova ordem. É essa inversão de sentidos nas relações entre esses dois âmbitos que marca a teorização educacional da segunda metade do século XX, cujos efeitos no ideário pedagógico se manifestam até os dias de hoje, mesmo decorridas três décadas do final daquele regime de exceção.

Com a inversão das relações entre ordem política e educação, os papéis pedagógicos se transmutam em papéis políticos, descaracterizando a escola em suas funções precípuas, como instituídas originariamente. Pode-se afirmar isso à luz do entendimento de que a pedagogia se pauta, ou deveria se pautar, pela assimetria das relações e pelo exercício da autoridade de quem ensina, enquanto que a política requer relações simétricas capazes de vincular os indivíduos num jogo de opiniões em busca de alguma forma de consenso.

No período da vigência do regime de exceção, no âmbito das escolas e no da academia em geral, se tornou hegemônica uma linha de pensamento, a da dialética marxista, que já não se orientava pela perspectiva de recuperação da ordem política nos termos propugnados pelas modernas democracias republicanas, mas pela instauração de uma ordem alternativa, a do socialismo. Afinal, estávamos no século XX e as esperanças de saída da situação se colocavam "do outro lado do muro" que, àquela altura, ainda não havia caído... Hoje se sabe que todos os regimes que se organizaram com base no ideário dialético-marxista se orientaram mais propriamente para o fim da política do que para a afirmação de suas potencialidades.

4. Essa situação de excepcionalidade quanto às liberdades democráticas ocorreu também em vários outros países, especialmente da América Latina, ao longo da segunda metade do século XX. 
E de que forma essas turbulências nas relações entre educação e ordem política se refletem na assim chamada profissão em crise do professor? A começar pelos seus alegados objetivos. O professor continua pensando que educar é transformar e libertar, sem saber dizer ao certo em que sentido transformar e do que propriamente libertar. No âmbito da escola, por sua vez, entende como intromissão indevida quaisquer demandas do Estado, como a da verificação do grau de aprendizagem do currículo através de avaliações empreendidas pelos órgãos de governo, por exemplo. Aliás, ele toma a própria definição de um padrão curricular nacional como uma imposição autoritária em seu âmbito de trabalho. E, por fim, o professor ainda encontra muita dificuldade para se assumir como alguém que desempenha uma função delegada pelo Estado, pois ainda mantém em relação a ele uma atitude de desconfiança, como de resto em relação às potencialidades da própria política de Estado.

Consideradas as lições do século XX, a saída para algumas das crises do presente, como a da educação, parece demandar inspiração no legado deixado pelos revolucionários do século XVIII. Isso porque, na esteira daqueles visionários, temos como falar de educação e da profissão docente em suas articulações positivas para com a sociedade, pois, à luz da ordem democrática e republicana, suas ações adquirem determinada configuração e sentido, diante do que é possível propor ajustes, reformulações, enfim, pensar com critério o seu fazer. 0 critério ou pano de fundo da educação republicana é o da política, entendida como opção de homens que, por si mesmos e sob o imperativo das muitas e variadas opiniões, instauram um modo de vida assentado no pressuposto das liberdades e responsabilidades individuais e coletivas. Trata-se de um modo de gerir a coisa pública sem quaisquer amparos ou direcionamentos a não ser os que emanam desse concerto de cumplicidades recíprocas. Essa noção de política assume o entendimento de que ninguém sabe ao certo qual rumo tomar, uma vez que isso não está inscrito nos homens e nem lhes é revelado de modo algum, com o que passa a ser de bom senso repartir a responsabilidade das escolhas com todos os envolvidos.

\section{A crise quanto ao foco da ação docente}

Hoje parece não haver professor que não se queixe do excesso de demandas que a ele são postas. Espera-se que ele dê conta de todas as variáveis capazes de interferir na educação dos seus alunos. Nesse sentido, esperam-se dele ações compensatórias pontuais e imediatas como as vinculadas à saúde, sexualidade, afetividade, cultura, entre outras. Além disso, espera-se que, no bojo do currículo que desenvolve, venham a se equacionar carências e desigualdades de diversas ordens, cujo enfrentamento e solução, em muitos dos casos, deveriam ser 
propriamente de responsabilidade da sociedade e de suas respectivas instâncias de organização política. Essa superestimação das possibilidades da atuação do professor resulta, por óbvio, em frustração e desânimo, configurando uma das dimensões da "profissão em crise".

É ao filósofo e educador Condorcet (1743-1794), que participou ativamente das atividades políticas vinculadas à Revolução Francesa, oferecendo grandes contribuições para o pensamento educacional republicano, que recorremos em busca do que consideramos uma visão mais realista acerca dos limites e possibilidades da educação. Na leitura de sua obra, surpreende como ele assume a posição de que cabe à educação tão-somente essa oferta (igual) de oportunidades, sem quaisquer escrúpulos em reconhecer as formas diferenciadas de aproveitamento que os indivíduos venham a ter com a educação que thes é ministrada. No seu dizer, "é impossível que uma instrução, mesmo quando igual para todos, não aumente a superioridade daqueles a quem a natureza favoreceu com uma organização mais feliz" (Condorcet, 2008, p. 18). E já em outra passagem diz:

Portanto, é ainda um dever da sociedade oferecer a todos os meios de adquirir os conhecimentos que todos possam obter com a força de sua inteligência com o tempo que puderem empregar para se instruir. Sem dúvida, disso resultará uma diferença maior em favor daqueles que possuem mais talento natural e a quem uma sorte independente deixa a liberdade de se consagrar mais anos ao estudo; mas, se essa desigualdade não submeter um homem a outro, se ela oferecer apoio ao mais fraco sem lhe impor um mestre, ela não será um mal nem uma injustiça; e certamente um amor pela igualdade que temesse aumentar o número de homens esclarecidos e tivesse medo de estender as luzes seria um amor bem funesto. (Condorcet, 2008, p. 21)

Pelo que se depreende dessa passagem, no âmbito do espírito iluminista, não havia qualquer constrangimento em constatar que, a partir de uma oferta igual de oportunidades, alguns indivíduos viessem a se destacar para o bem geral da humanidade. E é exatamente isso que Condorcet entendia não ser "um mal nem uma injustiça". Com base nessas recorrências, podemos afirmar que os republicanos do século XVIII atribuíam à escola, isso sim, a importante, embora modesta, tarefa de oferecer oportunidades iguais de acesso à instrução, mas do que não extraíam como consequência o que seria um aproveitamento igual dessas oportunidades.

Voltando aos tempos de hoje, parece evidente que se está fazendo aposta demasiadamente alta em relação ao trabalho do professor. A noção de currículo, nesse sentido, se ampliou de tal modo com a incorporação de dimensões e tarefas que parece já não sobrar espaço para as disciplinas. É isso que podemos dizer na esteira do impactante artigo do sociólogo britânico Michael Young em defesa de um “currículo centrado em disciplinas". Textualmente o sociólogo diz: 
[...] o currículo precisa ser visto como tendo uma finalidade própria - o desenvolvimento intelectual dos estudantes. Não deve ser tratado como um meio para motivar estudantes ou para solucionar problemas sociais. [...] Seria ingenuidade imaginar que qualquer currículo pudesse superar desigualdades geradas em outro lugar. (Young, 2011, p. 614; 620)

Em sua argumentação em defesa de um currículo centrado em disciplinas, Young diz que estas, as disciplinas, "são cruciais para o senso de identidade dos professores como membros de uma profissão". E acrescenta: "0 conhecimento da disciplina fornece aos professores a base de sua autoridade sobre os alunos" (Young, 2011, p. 617). Já em outro artigo, o mesmo autor refere-se a esse conhecimento também como "a base da autoridade dos professores e da confiança que a sociedade deposita neles como profissionais". (Young, 2007, p. 1300)

Pensamos que essa questão do foco da ação docente requer uma reflexão quanto ao próprio processo de formação de professores. Nesse sentido, e na esteira da crítica de Young, cabe perguntar se os currículos dos nossos cursos de licenciatura estão adequadamente constituídos para a formação de um professor cuja autoridade resulte do conhecimento aprofundado das disciplinas que irá ministrar. Será que efetivamente estamos formando professores para ensinar alguma coisa, uma disciplina em especial, ou um conjunto de conteúdos culturais que, por sua vez, vão fazer toda a diferença na vida dos seus futuros alunos? Essa questão do foco da ação do professor nos remete ao próximo tópico.

\section{A crise no que se refere ao professar}

Com relação à docência, entendemos haver uma crise do professar e que, por sua vez, articulamos diretamente com o tópico anterior, ou seja, com aquilo que analisamos como crise de foco da ação docente. Originalmente, e em sentido etimológico, professor tem o significado de confessar diante de todos, ou à vista de todos. Com o tempo, o professor passou a ser visto como aquele que "professa", que declara publicamente possuir conhecimentos em determinada área do saber e que, por isso, é capaz de transmiti-los. Analogamente ao que se espera do padre ou do pastor, cuja missão é professar uma determinada fé com base em sua experiência de vida, pode-se dizer que alguém é professor quando se torna apto a professar um determinado conhecimento, uma determinada disciplina. E, continuando com esta analogia, pode-se dizer que assim como igrejas destacam padres ou pastores para testemunharem a fé que consideram importante ser aprendida, assim também o Estado, enquanto representante da ordem política, destaca professores para "testemunharem" os conhecimentos que considera importantes serem aprendidos, no caso, e de modo especial, pelas novas gerações. 
Por óbvio assumimos aqui o entendimento de que a docência se expressa como testemunho da própria aprendizagem. Nesse sentido, para ser professor, é preciso ter aprendido antes o que se pretende ensinar, do que resulta como condição sua um alto investimento na própria formação, o que requer esforço, disciplina e dedicação. Investimento esse por vezes tacitamente sugerido como desnecessário, como nos casos em que a oferta de vagas em cursos de formação de professores vem acompanhada com apelos de marketing do tipo "estude quando quiser, aproveitando suas horas livres...", muito comum em ofertas de educação a distância, ou, então, "aula uma vez por semana". Pode-se imaginar que, se apelos desse tipo fossem feitos em ofertas de cursos como de medicina ou de alguma engenharia, por exemplo, muito provavelmente haveria denúncia de parte dos respectivos conselhos profissionais, alegando previsíveis riscos vinculados à atuação desses futuros profissionais.

De lembrança pessoal, trazemos a manifestação de alguém que acabava de entrar num curso de formação de professores e que parecia estar falando também por outros: "Professor, estamos estranhando o que você está pedindo: estudar, ler e entender textos difíceis, escrever o próprio texto... Até hoje nós passamos de ano a ano dando um jeito..." O que chama a atenção em uma fala dessas não é apenas a manifestação desse estranhamento quanto ao que seria o óbvio por parte de quem ingressa num curso superior, que é a disposição de estudar e aprender, mas a pressuposição implícita de que maiores esforços poderiam ser dispensáveis. Afinal, eles só aspiravam ser professores... Cabe aqui perguntar donde vem esse entendimento de que a carreira do magistério é factível para quem pouco estudou na vida ou pouco está a fim de estudar. Por acaso, teriam sido as experiências junto a professores que tiveram ao longo de suas vidas que thes teriam dado a entender isso?

Para além do já sugerido, a que mais se deve essa imagem de que a carreira docente pode prescindir de um alto investimento na própria formação? Na esteira das análises de Hannah Arendt (2002), podemos dizer que o justo contraponto que os diferentes movimentos de renovação pedagógica estabeleceram em relação à primeira tradição pedagógica, destacando as condições individuais e a experiência dos alunos, a importância do método, a consideração dos aspectos sociais e psicológicos que envolvem o processo de aprendizagem, entre outros, resultou na ideia de que ser professor implica tantos e diversificados saberes, que o da matéria a ser ensinada ficou obliterado. E isso, em nosso entender, se transpôs em boa medida para os próprios cursos de formação que, ao modo de uma didática geral, passaram a formar o professor em geral, como se tratando de um ofício em geral e já não vinculado a esse ou aquele campo de saber. E é exatamente em torno disso que Arendt traça considerações no ensaio "A crise da educação", surpreendente a cada leitura pela sua contundência e atualidade: 
Sob a influência da Psicologia moderna e dos princípios do Pragmatismo, a Pedagogia transformou-se em uma ciência do ensino em geral a ponto de se emancipar inteiramente da matéria efetiva a ser ensinada. Um professor, pensava-se, é um homem que pode simplesmente ensinar qualquer coisa; sua formação é no ensino, e não no domínio de qualquer assunto particular. [...] Como o professor não precisa conhecer sua própria matéria, não raro acontece encontrar-se apenas um passo à frente de sua classe em conhecimento. Isso quer dizer, por sua vez, que não apenas os estudantes são abandonados a seus próprios recursos, mas também que a fonte mais legítima da autoridade do professor, como a pessoa que [...] sabe mais e pode fazer mais que nós mesmos, não é mais eficaz. (Arendt, 2002, p. 231)

Na mesma linha crítica que identifica uma crise na educação exatamente pela inexistência de um conhecimento a ensinar, ou a professar, por parte do professor, o filósofo francês Clément Rosset afirma:

Se a escola é feita para ensinar, então é necessário que ela ensine alguma coisa [...]. A pedagogia acabou por suplantar a própria instrução. Temos hoje docentes que não sabem nada, mas possuem uma misteriosa ciência da educação, verdadeira mitologia dos tempos modernos. Resultado: desde há uma dezena de anos vemos chegar ao ensino superior estudantes analfabetos. (Rosset, 1993, p. 66)

E, com o foco já não propriamente num saber a ser aprendido, mas tão-somente numa pretensa arte de ensinar, já não se aprendem as próprias condições do aprender, entre as quais a disciplina intelectual. E o que seria essa disciplina? Em termos gerais, ela poderia ser conceituada como "capacidade de fazer algo que, mesmo sendo cansativo ou não nos dando prazer em si ou de modo imediato, o fazemos pela capacidade de visualizar o benefício futuro que dessa atitude ou esforço teremos" (Boufleuer e Fensterseifer, 2011, p. 391). Ou seja, trata-se de uma atitude daqueles que aprenderam a dimensionar o tempo, exclusividade dos homens, que com isso são capazes de se lançarem ao futuro, transcendendo o aqui e agora (Freire, 1987, p. 39ss). Mas, de tanto mal que se tem falado da disciplina, boa parte dos professores praticamente não a aprendeu e, por isso, também não a podem ensinar, com o que tanto professores como alunos apresentam dificuldades em relação a essa condição fundamental para as suas aprendizagens.

A disciplina, no processo de aprender, se expressa ao modo de um comparecimento do sujeito com suas experiências, suas referências e percepções, permitindo que, diante de alguma instigação ou dado novo, estas se estruturem de outro modo, convertendo-se em conhecimento novo exatamente ao incorporar-se no sujeito como "figuração" interna, como nova estrutura mental erigida em perspectiva própria. E nada disso ocorre sem empenho, sem esforço, sem um considerável consumo de energia mental. É essa disciplina que parece faltar nos espaços de formação, onde já nos acostumamos às diversas formas de displicência, como a entrada e saída da sala a qualquer momento, a 
ocupação com tarefas paralelas, como a de conferir o que apareceu de novo na rede social, entre outras formas incompatíveis com o processo de construção de novas percepções e habilidades, isto é, com o processo de aprendizagem.

Ao sugerir que a docência se encontra diante de uma crise do professar, estamos indicando uma quebra, ou descontinuidade, entre quem ensina e o conteúdo do ensinamento. Ou seja, o professor já não é a expressão viva e encarnada do conhecimento que está a transmitir, com o que não consegue dar mostras do diferencial que faria, para uma pessoa, ter construído as percepções e adquirido as habilidades pressupostas nesse conhecimento apresentado. 0 suposto conhecimento com que trabalha configura-se como elemento "terceiro" em relação a sua existência, com o que a sua aula já não passa de um "falso testemunho", o que todo aluno percebe desde o primeiro instante.

A crise ao modo como a identificamos neste tópico apresenta-se como perda de uma efetiva anterioridade pedagógica. Anterioridade no sentido de o professor ter aprendido antes e estabelecido uma relação de intimidade com o conhecimento que se propõe a comunicar. Afinal, se à pedagogia sempre foi atribuído um sentido de condução, como poderia alguém conduzir outros por caminhos nunca antes andados? A anterioridade a que nos referimos é aquela que caracteriza o professor no seu diferencial em relação ao conhecimento e que se expressa pelo domínio teórico-conceitual da matéria a ser ensinada, ou seja, o domínio do "currículo". É só mediante esse domínio que sua aula pode desdobrar-se nas muitas formas de comunicar esse saber aos alunos, configurando-se no que mais propriamente podemos chamar de "pedagogia". Essa distinção entre currículo e pedagogia, que nos parece fundamental para bem situar o trabalho do professor, a devemos a Michael Young. De acordo com o autor, currículo "se refere ao conhecimento que um país considera importante que esteja ao alcance de todos os estudantes"; já pedagogia "se refere às atividades dos professores para motivar os alunos e ajudálos a se engajarem no currículo e torná-lo significativo". (Young, 2011, p. 612)

\section{Imagens da docência: do professor “organista” para o professor "recepcionista"}

A propósito e como desdobramento do que no tópico anterior interpretamos como sendo uma crise do professar, passemos a refletir sobre a docência a partir de duas possíveis imagens ou metáforas ${ }^{5}$. Nesse sentido, há uma imagem da docência que remonta aos inícios da modernidade. Como se sabe, a sala de aula foi uma invenção moderna para o atendimento do princípio de "ensinar tudo a

5. Imagens ou metáforas servem para destacar determinadas características de alguma situação que queremos descrever ou sobre a qual nos propomos a refletir. Assim, elas possuem um alcance bem pontual e em conformidade com a intenção que motivou a recorrência a elas. 
todos e a muitos ao mesmo tempo". E é justamente de Comênio, considerado o pai da didática moderna, que nos vem uma imagem que reforça os traços de uma docência que hoje identificamos em crise. Em seu livro "Didática Magna", Amós Comênio propõe a metáfora do organista para caracterizar o que entende ser a identidade docente. Quem nos recupera essa metáfora, ou imagem, é o professor Wanderlei Geraldi, em sua obra "A aula como acontecimento". Citando Comênio:

Com efeito, assim como qualquer organista executa qualquer sinfonia, olhando para a partitura a qual talvez ele não fosse capaz de compor nem de executar de cor só com a voz ou com o órgão, assim também porque é que não há o professor de ensinar na escola todas as coisas, se tudo aquilo que deverá ensinar e, bem assim os modos como o há de ensinar, o tem escrito como que em partituras? (apud Geraldi, 2010, p. 84)

Na análise de Geraldi (2010), a metáfora do organista de Comênio, “que executa qualquer sinfonia mesmo não sabendo compô-la”, resultou na atribuição das seguintes características identitárias à atividade do professor:

Ser hábil para ensinar mesmo não sendo muito dotado; 2. sua função é comunicar le infundir) na juventude uma erudição já preparada, e não retirada da própria mente (isto é, não precisa ser produzida por ele próprio); 3. para exercer sua função, tudo se the dá nas mãos: o quê e o como ensinar (uma partitura já composta). (Geraldi, 2010, p. 84-85)

Geraldi continua a análise dizendo que as novas tecnologias da informação têm produzido, mais recentemente, outra identidade do professor em que ele

[...] já não mais se define por saber o saber produzido pelos outros, que organiza e transmite didaticamente a seus alunos, mas se define como aquele que aplica um conjunto de técnicas de controle na sala de aula... [mediado] pelo material didático posto na mão do aprendiz, cabendo ao professor o controle do tempo, da postura e dos comportamentos dos alunos durante esta relação com o conhecimento através do material didático. (Geraldi, 2010, p. 86-87)

Essa "nova identidade" docente está presente numa espécie de política de formação que pretende instaurar um sistema de ensino e de escolas que, como se pode dizer, seja à prova de professores.

Mesmo que em épocas passadas, de menor acesso ao saber sistematizado, o professor encontrava, de certa forma, a justificativa da sua condição em ser portador de dados e informações que seus alunos ignoravam (com o que poderíamos perdoar Comênio em sua metáforal. Nos tempos atuais, essa "razão de ser" da docência vem se tornando cada vez mais problemática. Problemática inclusive sob o ponto de vista de sua sustentabilidade econômica, já que portadores ou suportes de dados e de informações estão disponíveis a preços 
cada vez mais acessíveis e sob as mais diversas formas. E cabe aqui dizer que, enquanto essa perspectiva ou essa percepção da identidade do fazer docente não se modificar, será inútil qualquer esforço de valorização da categoria profissional dos professores. E poderíamos acrescentar que, em não se resolvendo a crise do professar, vamos deparar com uma "crise de profissão", crise do tipo de ocupação, como analisamos na primeira parte deste artigo, pois já não valerá a pena pagar por alguém que não passa de um suporte estático de dados e informações. Para isso a tecnologia pode apresentar soluções mais econômicas.

Se a imagem do "professor organista" não nos serve, teríamos, então, uma imagem alternativa? De nossa parte, vamos propor a imagem do "professor recepcionista", análogo àquele que acolhe os convivas de uma festa, por exemplo. Considerando esse exemplo, o recepcionista faz com que os convidados possam se sentir à vontade, que saibam dos motivos da festa, dos modos de ser e de se comportar convencionados etc. Afinal, os que estão chegando precisam saber do que está acontecendo para não cometer alguma gafe... Eles precisam saber que modos de ação são considerados aceitáveis, ou quais valores e regras estão pautando essa festa ou esse encontro.

A proposição da imagem do recepcionista para o docente pressupõe como sua tarefa a acolhida das novas gerações ao mundo. Ou seja, o professor é aquele que acolhe e orienta os que estão chegando. A recepção que cabe à escola fazer, através dos seus professores, se vincula à ordem cultural e social estabelecida. Afinal, há um reservatório de saberes que foi construído ao longo dos tempos e que configura o modo elegido como razoável de o homem se portar no mundo. É esse o mundo que temos e que somos, e no qual vamos acolhendo as novas gerações. Não significa que este mundo seja de todo bom, justo e verdadeiro. Ele traz a marca da precariedade e da provisoriedade, necessitando sempre de ajustes, de aprimoramentos. Mas é esse mundo que constitui a base e a referência imprescindível para as novas gerações encetarem suas próprias histórias.

A escola, para todos os efeitos, é o espaço em que fazemos a acolhida das novas gerações, em que buscamos fazer com que os que chegam se sintam minimamente à vontade. Os professores, enquanto "recepcionistas", contam os modos convencionados de ser e de se portar, os modos de interagir com o meio e os modos de se relacionar com os demais. Enfim, tentam familiarizar os que vêm chegando. Nesse sentido, cabe aos professores não apenas informar dos modos existentes e cultivados, mas de justificá-los para seus alunos, mostrando sua pertinência e validade, mediante o aporte de razões que possam entender. Sua tarefa é produzir um entendimento, oportunizar um aprendizado baseado na compreensão de razões.

E é aí que entra o trabalho propriamente pedagógico da escola, já que as novas gerações não aprendem por mera repetição, pelo simples fato de serem informados dos modos de ser e de interagir instaurados. Os alunos necessitam avaliar por si e com base nas suas percepções se esses modos de ser e de interagir 
fazem sentido. Necessitam das justificações daquilo que thes é apresentado como saber, como conhecimento. E isso torna a escola um lugar que opera sob condições específicas. Não no formato de informar, de transmitir, de guardar, de simplesmente reter o que foi dito. Nada "gruda" no aluno a não ser aquilo que ele é capaz de tomar como uma percepção razoável da vida e do mundo.

Assim, pode-se dizer que o currículo enquanto dimensão da cultura mediada pela docência deve ser expressão das percepções vivas que a geração presente se propõe a testemunhar diante daquela que está chegando. Somente dessa forma, como uma espécie de testemunho vivo, o professor conseguirá atestar a importância da aprendizagem dos conteúdos curriculares junto a seus alunos. Nesse sentido ele deverá superar o que seria uma apresentação neutra ou desinteressada de sua matéria, como se ela fosse algo alheio a sua vida. Deverá superar a imagem do "organista", para quem talvez seja possível, diante de uma plateia, interpretar uma música que ele mesmo nunca tenha apreciado ou compreendido em sua genialidade.

É por isso que nos orientamos, aqui, por um entendimento de que é primordial, no que se refere à questão da educação e da formação docente, o professor constituir-se como sujeito inserido na cultura, como quem tem uma intimidade e cumplicidade com ela e, porque não, uma relação positiva com a tradição cultural. Cumplicidade que Hannah Arendt considera imprescindível ao afirmar enfaticamente: "Qualquer pessoa que se recuse a assumir a responsabilidade coletiva pelo mundo não deveria ter crianças, e é preciso proibi-la de tomar parte em sua educação". (Arendt, 2002, p. 239)

0 entendimento da docência como testemunho vivo da cultura a ser tematizada através dos currículos escolares sugere que a primeira coisa a ser considerada na preparação de uma aula seja, de fato, a verificação do grau de intimidade que o professor possui com o conhecimento que pretende trabalhar com os alunos. Trata-se de uma espécie de exame de consciência prévio em que o professor se pergunta acerca dos motivos que encontraria em sua própria experiência para atestar a validade ou importância desse conteúdo que irá ministrar. Assim, o aspecto propriamente constitutivo da docência está em ter aprendido antes, em ter assumido como uma percepção sua o que, como professor, se propõe a ensinar.

Sabe-se que todo conteúdo cultural que consta do currículo escolar se engendrou historicamente através de algum processo discursivo que, por sua vez, resultou na sua validação. Diante disso, espera-se que o aprendizado anterior do professor tenha sido uma espécie de recapitulação desse processo, incluindo aí a identificação da problemática humana ou social desencadeadora desse discurso. Em tendo aprendido dessa forma o que consta como conceito, teoria, técnica ou valor a ser ensinado, o professor terá a noção exata, e possivelmente crítica, dos limites e alcances daquilo que propõe como dimensão da cultura a ser aprendida pelos seus alunos. Resumindo, cabe ao professor no processo de sua constituição: 
- Aprender antes o conhecimento a ser ministrado, incorporá-lo como uma percepção sua, como uma competência no âmbito da cultura, como um modo seu de se situar no mundo;

- Aprender em perspectiva própria, e através da pesquisa, para que o conhecimento se configure de modo original e novo para ele;

- Compreender o porquê da validade ou importância do conhecimento, as razões de esse conhecimento constar do currículo de sua disciplina de ensino;

- Fazer com que o conhecimento efetivamente passe por ele antes de este passá-lo ao aluno..., evitando que ele (o conhecimentol constitua um elemento "terceiro" em relação ao seu mundo (do professor), alheio à própria experiência de sua vida;

- Conferir ao conhecimento o caráter de um saber de homens, digno de ser apresentado para as novas gerações;

- Construir uma ideia ou compreensão preliminar em relação ao conhecimento, sabendo que esta necessitará ser testada ou revisada mediante ou após a interação com os alunos, o que significa que o professor, como qualquer um, não aprende de vez, isto é, de forma completa.

- Em síntese, antes de iniciar uma aula é necessário o professor fazer uma espécie de exame de consciência, perguntando-se: - Qual o significado para mim do assunto que me proponho abordar com meus alunos? Encontraria em mim motivos para atestar a importância de sua aprendizagem?

Com base nesses indicativos, cujo sentido se vincula a toda a argumentação anteriormente feita, entendemos que o professor possa ter uma boa orientação para o seu processo de constituição e de revisão contínua do seu fazer docente. Um fazer orientado, em última instância, ao estabelecimento de um elo humanitário entre as gerações mediante a reconstrução e renovação do legado tradicional e cultural de nosso mundo de homens. Trata-se de uma tarefa que necessita do reconhecimento de sua importância por parte da sociedade, mas que sempre se encontrará em débito se não puder contar com professores que carreguem em si, no seu modo de ser, de agir e de interagir, os sentidos culturais e sociais que gostaríamos que as novas gerações aprendessem.

\section{Referências}

ARENDT, Hannah. A crise na educação. In: Entre o passado e o futuro. São Paulo: Perspectiva, 2002, p. 221-247.

BOUFLEUER, José Pedro; FENSTERSEIFER, Paulo Evaldo. Disciplina intelectual: algumas reflexões a propósito da homenagem a um intelectual. In: BOMBASSARO, Luiz Carlos; DALBOSCO, Cláudio Almir; KUIAVA, Evaldo Antonio. Pensar sensível: 
homenagem a Jayme Paviani. Caxias do Sul: EDUCS, 2011, p. 387-398.

CONDORCET, Jean-Antonine-Nicolas de Caritat. Cinco memórias sobre a instrução pública. São Paulo: Editora UNESP, 2008.

ESTEVE Zarazaga, José Manuel. 0 mal-estar docente: a sala de aula e a saúde dos professores. 3. ed. Baurú: Edusc, 1999.

FREIRE, Paulo. Educação como prática da liberdade. 18 ed. Rio de Janeiro: Paz e Terra, 1987.

GERALDI, João Wanderley. A aula como acontecimento. São Carlos: Pedro \& João Editores, 2010.

MOURSHED, Mona. Entrevista concedida ao site Educar para Crescer. 2008.

Disponível em: < http://educarparacrescer.abril.com.br/gestao-escolar/entrevistamona-mourshed-403642.shtml >. Acesso em: 19 jan. 2013.

OLIVEIRA, Eloiza da Silva Gomes. O "mal-estar docente" como fenômeno da modernidade: os professores no país das maravilhas. Ciências \& Cognição, v. 7 , p. 27-41, 2006. Disponível em: http://www.cienciasecognicao.org/pdf/v07/M31677. pdf. Acesso em: 21 de jan. 2013.

ROSSET, Clément. A ciência da educação, mitologia dos tempos modernos. In: KECHIKIAN, Anita. Os filósofos e a educação (entrevistas). Lisboa: Edições Colibri, 1993, p. 63-67.

YOUNG, Michael. Para que servem as escolas? Educação e Sociedade. Campinas, v. 28, n. 101, p. 1287-1302, set./dez. 2007.

. 0 futuro da educação em uma sociedade do conhecimento: o argumento radical em defesa de um currículo centrado em disciplinas. Revista Brasileira de Educação. v. 16, n. 48, p. 609-623, set./dez. 2011.

Rebebido em janeiro de 2013

Aprovado em fevereiro de 2013

José Pedro Boufleuer é doutor em educação pela Universidade Federal do Rio Grande do Sul e professor da Universidade Regional do Noroeste do Estado do Rio Grande do Sul. Email: jospebouQunijui.edu.br 